OPEN ACCESS

Edited by:

Eline Vanassche,

KU Leuven Kulak, Belgium

Reviewed by:

Paige K. Evans,

University of Houston, United States

Laura Sara Agrati,

University of Bergamo, Italy

*Correspondence:

Melanie Basten

melanie.basten@uni-bielefeld.de

Specialty section: This article was submitted to

Teacher Education,

a section of the journal

Frontiers in Education

Received: 10 May 2021

Accepted: 16 July 2021

Published: 30 July 2021

Citation:

Schumacher $F$, Basten $M$, Großschedl J, Klatthaar M and Wilde M (2021) The Influence of Previous Biology Lessons on Prospective

Teachers' Beliefs About Learning Biology.

Front. Educ. 6:707746. doi: 10.3389/feduc.2021.707746

\section{The Influence of Previous Biology Lessons on Prospective Teachers' Beliefs About Learning Biology}

\author{
Fabian Schumacher ${ }^{1}$, Melanie Basten ${ }^{2 *}$, Jörg Großschedl ${ }^{3}$, Moritz Klatthaar ${ }^{2}$ and \\ Matthias Wilde ${ }^{2}$ \\ ${ }^{1}$ Center for Teaching and Learning, Bielefeld University, Bielefeld, Germany, ${ }^{2}$ Faculty of Biology, Biology Education, Bielefeld \\ University, Bielefeld, Germany, ${ }^{3}$ Faculty of Mathematics and Natural Sciences, Institute for Biology Education, University of \\ Cologne, Cologne, Germany
}

Professional teaching competence is significantly influenced by beliefs about learning. Prospective teachers start their teacher training at university with quite persistent beliefs about learning processes. Beliefs about learning can be differentiated into two perspectives: beliefs about student learning and beliefs about one's own learning. Theoretical considerations suggest that the latter influence beliefs about student learning and both perspectives are influenced by the way in which prospective teachers experienced their own lessons as pupils at school. We investigated how prospective biology teachers remembered their own biology lessons and how these experiences influenced their beliefs about learning regarding both perspectives. The sample consisted of 164 prospective biology teachers $\left(M_{\text {age }}=21.58\right.$ years, $S D_{\text {age }}=$ 2.5, $66.02 \%$ female) in Germany. Results of a simple mediation model indicate that previous experiences in biology lessons had an impact on both perspectives. Moreover, we found that the influence that previous lessons had on the beliefs about student learning was fully mediated by one's beliefs about own learning processes. This suggests that experiences from one's own schooling have an impact on how teachers view learning of their students. As implications for teacher training and future research, our findings suggest that both perspectives of beliefs need to be further taken into account and that an explicit focus on beliefs about teachers' own learning is needed.

\footnotetext{
Keywords: preservice biology teachers, science teacher education, teacher beliefs, teacher education, constructivism, teacher beliefs about teaching and learning
}

\section{INTRODUCTION}

Prospective teachers' beliefs about learning are relevant for their professional development during teacher education (Brown et al., 2013), because these beliefs are reflected in their quality of teaching (Buelens et al., 2002; Staub and Stern, 2002; Hartinger et al., 2006; Weißeno et al., 2013). As a part of a teacher's professional knowledge (Bromme, 1992; Dann, 2000; Kleickmann, 2008), these beliefs influence student learning success (Staub and Stern, 2002).

Beliefs about teaching and learning range on a continuum from instructivist to constructivist views (Porcaro, 2011; Zaruba et al., 2021). Researchers in the field of science teacher education advocate using a constructivist approach to teaching and learning (Treagust et al., 1996; Hartinger et al., 2006; Voss et al., 2013). Studies suggest, that the instructional behavior is related to prospective 
teachers' beliefs about learning processes (Stipek et al., 2001; Staub and Stern, 2002; Dubberke et al., 2008; Weißeno et al., 2013). For example, teachers who hold constructivist beliefs offer their learners more opportunities to make choices in the learning process. In such lessons, learners feel more self-determined and report higher levels of interest (Hartinger et al., 2006). The positive impacts of constructivist beliefs manifest themselves in, for example, increased learning success (Staub and Stern, 2002).

Theoretical considerations based on a small body of research suggest that the beliefs about learning are influenced by the learning environment the prospective teachers experienced during their schooling (Kagan, 1992a; Kagan, 1992b; Pajares, 1992; Skamp and Mueller, 2001; Woolfolk Hoy et al., 2006; DaSilva et al., 2007; Mellado et al., 2007; Markic and Eilks, 2013; Zaruba et al., 2021). In Germany, natural sciences are not taught as a single subject, but in three different subjects (i.e., chemistry, biology and physics). Such instruction requires subject-specific teacher training in which subject-specific knowledge and beliefs are acquired (see Großschedl et al., 2019). School lessons in Germany are typically divided into 45-min intervals and can include segments of instruction as well as segments of experiments. In the current study, we focus on prospective biology teachers. The findings regarding the implementation of constructivist teaching styles in German secondary biology classes are based on little research (Fischer et al., 2003; Dorfner et al., 2017). However, constructivist didactics has been the dominant paradigm in biology teacher education for more than two decades in Germany (Hartinger et al., 2006; Voss et al., 2013). Hence, the aim of this study was to examine how prospective biology teachers' previously experienced biology school lessons affect their beliefs about learning.

\section{THEORY}

\section{Beliefs About Learning}

Research has brought beliefs about learning to center stage (Prawat, 1992) because they influence the classroom learning environment in terms of teachers' action-guiding preferences (Baumert et al., 2004). These preferences are considered to be a part of teachers' professional competence (Dann, 2000; Kleickmann, 2008; Baumert and Kunter, 2013). Beliefs about learning biology refer to a specific domain and are assigned to the subject-specific pedagogical content knowledge (PCK) for science (Magnusson et al., 1999). In line with Magnusson et al. (1999), we classify beliefs about learning biology as a specific facet of preservice teachers' PCK: "concepts of learning in a scientific subject" (Bromme, 1992; Borko and Putnam, 1996; Krauss et al., 2008; Kleickmann et al., 2010). Like Kleickmann et al. (2010), we conceptualize beliefs as an amalgam of epistemologically validated knowledge aspects (Magnusson et al., 1999) and the teachers' subjective experiences and assumptions (Kleickmann, 2008; Lloyd and Wilson, 1998; Pajares, 1992; Richardson, 1996; Richardson, 2003).

There are numerous views on teaching and learning which can be sorted on a continuum from instructivist to constructivist views (Porcaro, 2011). The current study focuses on constructivist beliefs in order to concentrate on a clearly defined set of beliefs that have been advocated for regarding the teaching of the natural sciences (Widodo and Duit, 2004; Cakir, 2008). Constructivist beliefs have been well described in pertinent literature (Buelens et al., 2002; Dubberke et al., 2008; Kleickmann et al., 2010). From a constructivist point of view, learning is an active, constructive, intentional, conscious, reflexive, and social process (Drechsel, 2001; Glasersfeld, 2001; Reinmann and Mandl, 2006). Not all of those characteristics are distinct from other learning theories (Porcaro, 2011; Yilmaz, 2011) and Terhart (2003) assumes that characteristics describing constructivist learning might actually describe good learning from every theoretical point of view. A key assumption of the constructivist learning approach is that learners need to integrate new information into their own thinking processes and individual knowledge structures (Dubs, 2009). In the constructivist epistemology the teacher is not able to induce the construction of clearly defined knowledge (Porcaro, 2011). Thus, the focus is on the learning process itself and not on the result (Dubs, 1995). Constructivist teaching is characterized by allowing for individual learning paths (Buelens et al., 2002; Marsch et al., 2009) and students' own wording and solutions (Reinmann and Mandl, 2006) as well as errors (Dubs, 1995). During collaborative phases students negotiate the intersubjective meaning of what they experienced and thought, individually (Porcaro, 2011). The role of the teachers is to facilitate students' own knowledge construction (Porcaro, 2011) by providing appropriate tasks (Marsch et al., 2009) and relating the course content and methods to the previous experiences and interests of their students (Dubs, 1995). The tasks should enable students to discover principles which are presented in their authentic contexts (Marsch et al., 2009). To sum up constructivist beliefs about teaching and learning should reflect a learner-centered teaching style and learning as an active coconstruction of knowledge.

\section{Perspectives of Beliefs}

Brauer et al. (2015) differentiate beliefs about learning into two perspectives: beliefs about student learning and about one's own learning processes (Brauer and Wilde, 2018). However, the term beliefs about learning has generally been used synonymously with beliefs about students' learning and no distinction between the two perspectives was made. To successfully professionalize prospective teachers, a distinct view of those two perspectives seems crucial (Brown et al., 2013).

The teaching profession is a special occupational field because prospective teachers have already gained previous experiences prior to their formal training at universities. Pajares (1992) describes prospective teachers as "insiders" who have gained many years of first-hand experience (p. 323; Woolfolk Hoy et al., 2006). Kleickmann et al. (2012) point out that, as a result, prospective teachers start their university education with various distinct conceptions about the teaching and learning process, which are largely based on their own experiences as students at school (Windschitl, 2003). These experiences with various teaching and learning styles influence 
their beliefs regarding both perspectives, their own learning and students' learning (Huibregtse et al., 1994; Stofflett and Stoddart, 1994; Da-Silva et al., 2007). This can be explained by anticipatory socialization (Kohli, 1986), which describes an anticipatory preoccupation with the field of action even before the actual activity begins. Kagan (1992b) presumes that the subjective assumptions are preferred over the formally acquired knowledge in university education.

A distinct analysis of the two perspectives reveals that beliefs about student learning are influenced by beliefs about one's own learning processes (Brauer and Wilde, 2018; Kleickmann et al., 2012; Meyer, Tabachnick et al., 1999; Schumacher et al., 2018). This can be explained by the origin of both perspectives: At first prospective teachers develop beliefs about their own learning process and subsequently form their beliefs about student learning (Meyer et al., 1999). Prospective teachers' experiences from their own school time can lead them to justify learning approaches and deal with the learning difficulties of their students on the basis of their own experiences and preferences (Nespor, 1987; Kagan, 1992b; Simmons et al., 1999; Woolfolk Hoy et al., 2006; Kellner et al., 2011). This is particularly the case for prospective teachers without any practical experience (Meyer et al., 1999) because they have not had sufficient opportunities to reflect on their views on teaching and learning. When it comes to those teachers, Kagan (1992a) suggests instructing them on the basis of their previous educational experiences. Brown et al. (2013) concur and argue that the lessons they have experienced should also be integrated into teacher training in order for them to break the didactic cycle of learning and teaching. To the authors' knowledge there are only a few international studies that explore the instructional quality of the present teaching in schools. For mathematics, Handal (2003) was able to show that teachers predominantly represent instructivist beliefs about teaching and learning. Koballa et al. (2000) describe the majority of teachers' beliefs in chemistry as reproductive. Such a tendence was found in other studies [Klinghammer et al., 2016 (physics); Ferguson and Bråten, 2018; Southerland and Gess-Newsome, 1999 (not subjectspecific)]. The few existing studies indicate that German prospective biology teachers generally hold constructivist beliefs about learning at the beginning of the university-level teacher training (Schumacher and Wilde, 2021; Brauer et al., 2014; Markic et al., 2006). However, there is still a lack of conclusive evidence about the design of recent biology learning environments at German schools (Dorfner et al., 2017; Fischer et al., 2003; Widodo and Duit, 2004; Widodo and Duit, 2005).

\section{HYPOTHESES}

Prospective teachers' beliefs about learning are rooted in their experiences from their own school time (Kagan, 1992b; Skamp and Mueller, 2001; Da-Silva et al., 2007). Several studies have investigated the influence of the lessons (prospective) teachers experienced at school on the beliefs about learning (Kagan, 1992b; Woolfolk Hoy et al., 2006). However, these findings are based on mostly qualitative studies with small sample sizes. In line with the findings of these studies, previously experienced biology lessons were assumed to be a predictor of the development of beliefs about constructivist student learning. Because beliefs about one's own learning process influence teachers' beliefs about student learning, they are considered to be a mediator (Brauer and Wilde, 2018; Meyer et al., 1999). Thus, we hypothesized that:

The biology lessons prospective teachers experienced during their schooling predict the presence of constructivist beliefs about student learning. This direct relationship is mediated by the constructivist beliefs about one's own learning processes.

\section{METHODS}

\section{Sample and Procedure}

The sample consisted of $N=164$ prospective secondary schoollevel biology teachers $\left(M_{\text {age }}=21.58\right.$ years, $S D_{\text {age }}=2.5,66.02 \%$ female) from one university in North Rhine-Westphalia, Germany. A questionnaire was administered during the first session of the lecture "Introduction to Biology Education". Participation in the survey was a voluntary part of the lecture. This was the first time these students were confronted with didactic topics in their biology teacher training at university, although the lecture was 1.5 years after the start of their university education. At the beginning of their teacher training in biology, students take courses on the basics of biology. Didactic topics in biology are first taught in the examined lecture (Bielefeld University, 2021). Thus, it can be assumed that this was the first time that they had been confronted with constructivist views about teaching and learning biology during the first phase of teacher training at university. This time point was selected in order to be able to assess the subject-specific constructivist beliefs without inducing a potential bias in their answers due to their university studies. Having heard about constructivist biology teaching before assessing prospective teachers' experiences at school and their beliefs about biology learning would have influenced the knowledge facet of their PCK and might also have confounded their memories about their schooling.

\section{Measurement}

Biology lessons experienced at school. An adapted and extended version of the short questionnaire for the analysis of a constructivist learning process (Basten et al., 2015) was used to assess the participants' experienced secondary-level biology lessons (EBL; see Table 1 and Supplementary Material). The original instrument was designed and validated to assess the constructivist design characteristics of a school lesson according to Reinmann and Mandl (2006). In our study we adapted the instrument by asking the participants to rate the learning environments in the last biology lessons they experienced at school. This retrospective analysis offers the possibility to record the experienced school biology lessons quantitatively without a longitudinal data set. Five-point rating scales coded from 0 to 4 were used 
TABLE 1 |Scales are shown below. For each scale, the number of items and the internal consistency (Cronbach's alpha) is listed. An example item for each scale is provided. Previously experienced biology lessons (EBL), constructivist beliefs about student learning (BSL) and constructivist beliefs about one's own learning processes (BOL).

\begin{tabular}{ll} 
Scale (item number) & $\quad$ Example \\
\hline EBL (27) & "Important for the learning process of school students is that they can develop their own ideas." \\
BSL (7) & "When it comes to my learning process it is important that I can develop my own ideas."
\end{tabular}

TABLE 2 | Means, standard deviations and Pearson correlations of previously experienced biology lessons (EBL), constructivist beliefs about student learning (BSL) and constructivist beliefs about one's own learning processes (BOL).

\begin{tabular}{lccccc}
\hline & $\boldsymbol{M}$ & SD & $\mathbf{1}$ & $\mathbf{2}$ & $\mathbf{3}$ \\
\hline 1 EBL & 2.55 & 0.54 & - & - & - \\
$2 \mathrm{BOL}$ & 4.46 & 0.86 & $0.37^{\mathrm{a}}$ & - & - \\
3 BSL & 5.02 & 0.62 & $0.32^{\mathrm{a}}$ & $0.53^{\mathrm{a}}$ & -
\end{tabular}

Scale EBL coded from 0 to 4; Scales BSL and BOL coded from 0 to 6; ${ }^{a} \mathrm{p}<0.001, \mathrm{~N}=164$

TABLE 3 | Analysis of the simple mediation model to investigate the mediating effect of constructivist beliefs about one's own learning processes (BOL) on the influence of previously experienced biology lessons (EBL) and on beliefs about constructivist student learning (BSL).

\begin{tabular}{|c|c|c|c|c|c|c|c|}
\hline Criterion & Predictor & B & SE(B) & $\beta$ & $p$ & LLCI & ULCI \\
\hline \multicolumn{8}{|c|}{ Model $1 \mathrm{R}^{2}=0.10, F(1,162)=16,57, p<0.001$} \\
\hline BSL & EBL & 0.43 & 0.11 & 0.32 & $<0.001$ & 0.22 & 0.64 \\
\hline \multicolumn{8}{|c|}{ Model $2 \mathrm{R}^{2}=0.13, F(1,162)=24,55, p<0.001$} \\
\hline $\mathrm{BOL}$ & $\mathrm{EBL}$ & 0.69 & 0.14 & 0.37 & $<0.001$ & 0.42 & 0.97 \\
\hline \multicolumn{8}{|c|}{ Model $3 R^{2}=0.30, F(2,161)=30,40, p<0.001$} \\
\hline \multirow[t]{2}{*}{ BSL } & EBL & 0.19 & 0.11 & 0.14 & ns & -0.02 & 0.41 \\
\hline & $\mathrm{BOL}$ & 0.34 & 0.05 & 0.48 & $<0.001$ & 0.25 & 0.44 \\
\hline
\end{tabular}

regression coefficient $B ; S E(B)=$ standard error of $B$; standardized regression coefficient $\beta$; ns not significant; $L L C I=$ lower level of confidence interval; $U L C I=$ upper level of confidence interval; $\mathrm{N}=164$.

( 0 = "strongly disagree" to $4=$ "strongly agree"). Internal consistency, reported as Cronbach's alpha, was satisfactory for both scales (see Table 1; Lienert and Raatz, 1998).

Beliefs about constructivist learning. An extended version of the C-questionnaire, which assesses the constructivist beliefs about learning of prospective biology teachers, was applied (Brauer et al., 2015). The questionnaire was specifically designed for students who aim to become biology teachers and is the only published and validated instrument, which assesses both perspectives - the constructivist beliefs about one's own learning processes (BOL) and beliefs about student learning (BSL) - with two scales (Brauer and Wilde, 2018). Seven-point rating scales coded from 0 to 6 were used $(0=$ "not true at all" to 6 = "totally true"). Internal consistency, reported as Cronbach's alpha, was also satisfactory (see Table 1 and Supplementary Material).

\section{Statistics}

The statistical analysis was executed with IBM SPSS Statistics 26. A simple mediation analysis with the SPSS macro PROCESS 3.3 (Hayes, 2018) was performed. The dependent variable beliefs about constructivist student learning $(Y)$ was hypothesized to be predicted by the independent variable previously experienced biology lessons $(X)$. The prediction of $\mathrm{X}$ on $\mathrm{Y}$ is mediated by the assumed mediator beliefs about one's own learning processes $(M)$. To estimate the significance of the indirect effect, we calculated the $95 \%$ confidence intervals based on the bootstrap resampling method with 10,000 iterations together with heteroscedasticity consistent standard errors (Davidson and MacKinnon, 1993). If the confidence interval for the indirect effect did not include zero, there was a significant mediation effect (Hayes, 2018).

\section{RESULTS}

We were interested in the effects of the students' previously experienced biology lessons at school on their current beliefs about their own learning processes and beliefs about student learning. All variables correlated significantly with average to high effect sizes (Cohen, 1988; see Table 2).

A simple mediation model was performed to analyze whether the previous biology lessons at school predicted constructivist beliefs about student learning and whether the direct path would be mediated by the constructivist beliefs about one's own learning processes. Table 3 provides the results of the regression analyses.

A significant effect of previously experienced biology lessons at school on constructivist beliefs about student learning was observed (Model 1, total effect $c$ : $\beta=0.32, p<0.001$ ). After entering the mediator, the previously experienced biology lessons significantly predicted the mediator (constructivist beliefs about one's own learning processes; Model 2, $a$ : $\beta=0.37, p<0.001$ ). In turn, the mediator constructivist beliefs about one's own learning processes predicted the beliefs about constructivist student learning significantly (Model 3, $b: \beta=0.48, p<0.001$ ). After entering the mediator into the model, the direct effect of previously experienced biology lessons on constructivist beliefs about student learning was no longer significant (Model 3, direct effect $c^{\prime}: \beta=0.14, n s$ ). As a result, the relationship between the students' previously experienced biology lessons at school and the constructivist beliefs about student learning was fully mediated by the constructivist beliefs about one's own learning processes [indirect effect $a b: \beta=0.18,95 \%-\mathrm{KI}(0.10$, $0.26)$ ]. For an overview of the results, the simple mediation model is illustrated in Figure 1. 


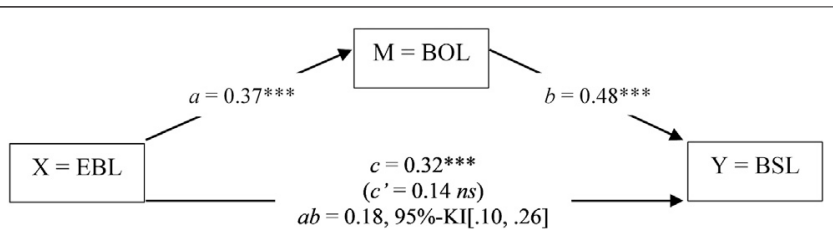

FIGURE 1 | Simple mediation model to investigate the mediating effect of constructivist beliefs about one's own learning processes (BOL) on the influence of previously experienced biology lessons (EBL) on constructivist beliefs about student learning (BSL) in the form of a statistical diagram. Standardized regression coefficients are reported. Notes. $c=$ total effect of $X$ on $\mathrm{Y} ; a=\mathrm{X}$ on $\mathrm{M} ; b=\mathrm{M}$ on $\mathrm{Y} ; c^{\prime}=$ direct effect of $\mathrm{X}$ on $\mathrm{Y} ; a b=$ indirect effect of $\mathrm{X}$ on $\mathrm{y} ;{ }^{* \star} \mathrm{p} p<0.001$

\section{DISCUSSION}

In our study, we focused on understanding the origin of prospective biology teachers' beliefs about learning. We wanted to analyze whether their beliefs about student learning were influenced by the biology lessons they had experienced during their school time. Furthermore, we were interested in whether this relationship was mediated by their beliefs about their own learning processes.

The influence of prospective teachers' experienced lessons at school on their beliefs has been discussed in previous studies (Pajares, 1992; Da-Silva et al., 2007; Mellado et al., 2007). However, there was a lack of empirical evidence for their assumed relationship. This study extends the understanding of the influence of future teachers' own experiences as students at school on their beliefs about learning by distinguishing beliefs about students' biology learning and own biology learning (Brauer et al., 2015; Brauer and Wilde, 2018; Schumacher et al., 2018). As a further contribution to the existing findings, this study conducted a regression analysis of the relationship between experienced lessons at school and beliefs about learning. It could be shown that the beliefs about one's own learning had an impact on the beliefs about student learning among prospective teachers at the beginning of their university-level teacher education. Furthermore, the effect of the experienced biology lessons at school on the beliefs about students' biology learning was fully mediated through prospective teachers' beliefs about their own biology learning. Therefore, it can be assumed that the currently predominant focus on (prospective) teachers' beliefs about their students' learning (Baumert and Kunter, 2013) falls short.

As implications for teacher training and future research, our findings rather suggest that the perspective of beliefs about one's own learning needs to be taken into account, additionally, and that an explicit focus on experiences from future teachers' own schooling is needed (Kagan, 1992b). Moreover, the development of these two perspectives of beliefs during teacher education needs to be analyzed more closely. The awareness of the two belief perspectives should be facilitated during teacher training since (prospective) teachers have to counter the problem of transferring one's own learning difficulties to their students' difficulties (Nespor, 1987; Kagan, 1992a; Simmons et al., 1999; Woolfolk Hoy et al., 2006). In tertiary-level teacher education, little attention has been paid to students' previous experiences at school and their beliefs about their own learning processes. Thus, the knowledge and experiences the prospective teachers acquire during their school time are intended to be "replaced" rather than reflected on when it comes to future practice. As a result, previously formed beliefs about learning are deepened without adequate reflection (Hellmann, 2019). Teacher education programs need to reveal these deeply rooted beliefs in order to help students understand how they influence the way they develop learning environments for their learners (Mellado et al., 2007; Kellner et al., 2011; Fives et al., 2015). Our study measured the prospective teachers' beliefs about learning biology from two perspectives and their relationship to experiences at school. In a next step, future studies should apply a longitudinal design in order to track the development of the beliefs during first and potentially second phase of teacher training. Future research should also assess additional variables related to the personal learning biography of the prospective teachers in order to gain a deeper insight into the development of their beliefs. There were also some limitations to our study. The results of the retrospective assessment of the experienced biology lessons at school need to be interpreted carefully. The problem with this type of retrospective longitudinal study is that memory effects and selective perception cannot be controlled for (Döring and Bortz, 2016). The study was conducted during the first lecture of a course on the theories about learning biology. Hence, the constructivist approach is one of the main topics that would be covered in the course at a later date. Therefore, there is the possibility that students answered in a socially desired manner. Still, the present study can serve as a basis for further longitudinal studies. To address the issue of a potentially socially desired answer another measuring point could be added at the end of the lecture. This would also further expand the understanding of the development of teachers' beliefs. Since all participants of this study were recruited from the same university the inferences that can be drawn from it are limited. It would therefore be beneficial to extend it to other universities for a more diverse sample that allows for more general conclusions. Furthermore, the study focused on prospective biology teachers and the beliefs about teaching and learning biology. From a cross-cultural perspective, the specific focus on biology can be considered fragmentary regarding a comprehensive science education. On the other hand, the singular condition in a. o. Germany that science is taught as three distinct subjects provides the opportunity to investigate different aspects of science, individually. A comparison of findings on beliefs about science teaching and learning and beliefs about biology, physics and chemistry teaching and learning, respectively, might provide a more detailed view on (prospective) teachers' beliefs as well as the relationships among them. These considerations should be taken up in future research.

Finally, the effect sizes of the regression coefficients were moderate which means that the beliefs about one's own learning as well as indirectly the beliefs about student learning cannot be fully explained by prospective teachers' experiences during their own school time. Further studies should aim at revealing other factors that substantially influence prospective teachers' beliefs about teaching and learning biology as well as other subjects. 


\section{CONCLUSION FOR EDUCATIONAL PRACTICE}

One way to increase prospective teachers' awareness of the beliefs they hold (Brown et al., 2013) could be to use interventions based on the theoretical concept of research-based learning (Huber, 2009). While conducting their own research projects on teaching methods, students deal with authentic teaching problems and at the same time are required to engage in (self-)reflection (Huber, 2009). The aim of this approach is to promote future teachers' ability to reflect in the sense of a "reflective practitioner" (Schön, 1987). This can be achieved, in particular, through university training (Hatton and Smith, 1995; Kellner et al., 2011). Various studies have found positive results stemming from this form of university guidance (Brouwer and Korthagen, 2005; Gröschner et al., 2013; Schumacher et al., 2018). Reflection on one's beliefs about learning should explicitly include raising the two perspectives. This kind of university teaching might also foster a preference for the use of constructivist teaching methods as a biology teacher. Another way to model constructivist teaching might be teaching the concept of constructivism using other forms of inquiry learning not attached to student research projects on teaching methods instead of a lecture (Windschitl, 2003). These approaches might be a more fruitful way to break through the didactic cycle of learning and teaching mentioned by Huibregtse et al. (1994) because reflecting on one's beliefs regarding both perspectives is indispensable for changing established views on learning and teaching (Gregoire, 2003; Philipp, 2007). Addressing this issue at an early stage of teacher training appears to be the best starting point since prospective teachers are more open to reform-related changes in their beliefs than experienced teachers (Fives and Buehl, 2012). In future studies, the effects of such types of research- or inquiry-based learning activities on future teachers' constructivist beliefs should be investigated.

A common assumption in the context of teacher education is that "teachers teach the way they were taught" (e.g., Lortie, 1975, "Apprenticeship of observation"). This means that teachers already have a rich educational biography with quite persistent beliefs about good and bad teaching before they actually start their teacher education at university. To verify this assumption, it is important to assess how teachers were taught in their own school years. This was addressed in this study, by assessing the experiences of their own biology lessons at school. In order to be able to deduce whether these experiences from their own school biology lessons might have an influence on their future teaching, the connection between experiences and beliefs about learning were investigated. The study thus provided

\section{REFERENCES}

Basten, M., Greiff, S., Marsch, S., Meyer, A., Urhahne, D., and Wilde, M. (2015). Kurzskala zur Messung gemäßigt konstruktivistischer Prozessmerkmale (Kurz-PgK) im Biologieunterricht Short scale for Measuring Moderately Constructivist Process Characteristics (short PgK) in Biology Lessons. Erkenntnisweg Biologiedidaktik, 43-57.

Baumert, J., Kunter, M., Brunner, M., Krauss, S., Blum, W., and Neubrand, M. (2004). "Mathematikunterricht aus Sicht der PISA - Schülerinnen und -Schüler und ihrer Lehrkräfte [Teaching maths from the PISA perspective: Leaners and their teachers]," in Der Bildungsstand der Jugendlichen in Deutschland Ergebnisse des zweiten internationalen Vergleichs [The state of education of empirical evidence and a better understanding of the much-described phenomenon mentioned by Lortie (1975) and other authors. Stofflett (1994) points out that reflecting on one's own experiences (conceptual change) is a necessary condition for a successful teacher education in order to break the didactic circle of teaching and learning described above (Huibregtse et al., 1994). In the context of the conceptual change approach (Patrick and Pintrich, 2001), pre-service teachers should be exposed to alternative teaching and learning methods while engaging in research-based learning in order for them to scrutinize their own beliefs and the experiences from their own school lessons.

\section{DATA AVAILABILITY STATEMENT}

The raw data supporting the conclusions of this article will be made available by the authors, without undue reservation.

\section{ETHICS STATEMENT}

Ethical review and approval was not required for the study on human participants in accordance with the local legislation and institutional requirements. Written informed consent for participation was not required for this study in accordance with the national legislation and the institutional requirements.

\section{AUTHOR CONTRIBUTIONS}

All authors listed have made a substantial, direct, and intellectual contribution to the work and approved it for publication.

\section{FUNDING}

We acknowledge support for the publication costs by the Open Access Publication Fund of Bielefeld University.

\section{SUPPLEMENTARY MATERIAL}

The Supplementary Material for this article can be found online at: https://www.frontiersin.org/articles/10.3389/feduc.2021.707746/ full\#supplementary-material

the youth in Germany - The results of the second international comparative study]. Editors M. Prenzel, J. Baumert, W. Blum, R. Lehmann, D. Leutner, M. Neubrand, et al. (Münster: Waxmann), 314-354.

Baumert, J., and Kunter, M. (2013). "The COACTIV Model of Teachers' Professional Competence," in Cognitive Activation in the Mathematics Classroom and Professional Competence of Teachers. Editors M. Kunter, J. Baumert, W. Blum, U. Klusmann, S. Krauss, and M. Neubrand (New York: Springer), 25-48. doi:10.1007/978-1-4614-5149-5_2

Bielefeld University (2021). Modulhandbuch Biologie/Bachelor of Science: Kernfach Module Manual Biology/Bachelor of Science: Core Subject. Available at: https://ekvv.uni-bielefeld.de/sinfo/publ/variante/62556682; jsessionid=48DC0834A3053DA270FD69A841539985 
Borko, H., and Putnam, R. T. (1996). "Learning to Teach," in Handbook of Educational Psychology. Editors D. C. Berliner and R. C. Calfee (Washington: Macmillan), 673-708.

Brauer, H., Balster, S., and Wilde, M. (2014). Lehr - und Lernvorstellungen künftig Lehrender zum Lernen von Schülerinnen und Schülern im Fach Biologie Teacher and Learner Beliefs of Teaching and Learning in Biology. Zeitschrift für Didaktik der Naturwissenschaften 20 (1), 191-200.

Brauer, H., Balster, S., and Wilde, M. (2015). Entwicklungeines Messinstruments zur Erhebung von Lernvorstellungen von Angehenden Lehrenden Developing an Instrument to Measure Preservice Teachers' Beliefs of Learning. Psychologie Erziehung Unterricht 62 (3), 188-204.

Brauer, H., and Wilde, M. (2018). Do Science Teachers Distinguish Between Their own Learning and the Learning of Their Students? Res. Sci. Education 48 (1), 105-116.

Bromme, R. (1992). Der Lehrer als Experte. Zur Psychologie des professionellen Wissens [The teacher as an expert. On the psychology of professional knowledge]. Bern: Hans Huber.

Brouwer, N., and Korthagen, F. (2005). Can Teacher Education Make a Difference?. Am. Educ. Res. J. 42 (1), 153-224. doi:10.3102/00028312042001153

Brown, P., Friedrichsen, P., and Abell, S. (2013). The Development of Prospective Secondary Biology Teachers PCK. J. Sci. Teach. Edu. 24, 133-155. doi:10.1007/ s10972-012-9312-1

Buelens, H., Clement, M., and Clarebout, G. (2002). University Assistants' Conceptions of Knowledge, Learning and Instruction. Res. Edu. 67, 44-57. doi:10.7227/rie.67.5

Cakir, M. (2008). Constructivist Approaches to Learning in Science and Their Implications for Science Pedagogy: A Literature Review. Int. J. Environ. Sci. Edu. 3 (4), 193-206.

Cohen, J. (1988). Statistical Power Analysis for the Behavioral Sciences. 2nd ed. Hillsdale, NJ: Lawrence Erlbaum.

Da-Silva, C., Mellado, V., Ruiz, C., and Porlán, R. (2007). Evolution of the Conceptions of a Secondary Education Biology Teacher: Longitudinal Analysis Using Cognitive Maps. Sci. Edu. 91 (3), 461-491.

Dann, H.-D. (2000). "Lehrerkognitionen und Handlungsentscheidungen," in Lehrer-Schüler-Interaktion. Pädagogische-psychologische Aspekte des Lehrens und Lernens in der Schule [Teacher-learner interaction. Pedagogicalpsychological aspects of teaching and learning at school]. Editor M. K. W. Schweer (Opladen: Leske \& Budrich), 79-108. doi:10.1007/978-3322-97477-8_4

Davidson, R., and MacKinnon, J. G. (1993). Estimation and Inference in Econometrics. Oxford University Press.

Dorfner, T., Förtsch, C., and Neuhaus, B. J. (2017). Die methodische und inhaltliche Ausrichtung quantitativer Videostudien zur Unterrichtsqualität im mathematisch-naturwissenschaftlichen Unterricht. ZfDN 23, 261-285. doi:10.1007/s40573-017-0058-3

Döring, N., and Bortz, J. (2016). Forschungsmethoden und Evaluation in den Sozial- und Humanwissenschaften [Research methods and evaluation in the social and human sciences. Berlin, Heidelberg: Springer. doi:10.1007/978-3642-41089-5

Drechsel, B. (2001). Subjektive Lernbegriffe und Interesse am Thema Lernen bei angehenden Lehrpersonen [Subjective concepts of learning and preservice teachers' interests in the topic of learning]. Münster: Waxmann. doi:10.1142/ 4818

Dubberke, T., Kunter, M., McElvany, N., Brunner, M., and Baumert, J. (2008). Lerntheoretische Überzeugungen von Mathematiklehrkräften. Z. für Pädagogische Psychol. 22 (3-4), 193-206. doi:10.1024/1010-0652.22.34.193

Dubs, R. (1995). Konstruktivismus: Einige Überlegungen aus der Sicht der Unterrichtsgestaltung [Constructivism: Some considerations from the perspective of teaching organization]. Z. für Pädagogik 41 (6), 889-903.

Dubs, R. (2009). Lehrerverhalten. Ein Beitrag zur Interaktion von Lehrenden und Lernenden im Unterricht [Teacher behaviour. A contribution to the interaction between teachers and students in the classroom]. Stuttgart: Steiner.

Ferguson, L., and Bråten, I. (2018). Student Teachers Beliefs about Learning, Teaching, and Teaching Knowledge. Teach. Edu. Pract. 31 (3), 348-365.

Fischer, H. E., Klemm, K., Leutner, D., Sumfleth, E., Tiemann, R., and Wirth, J. (2003). Naturwissenschaftsdidaktische Lehr-Lernforschung: Defizite und Desiderata [Science education research: deficits and desiderata]. Z. für Didaktik der Naturwissenschaften 9, 179-209.
Fives, H., and Buehl, M. M. (2012). "Spring Cleaning for the "messy" Construct of Teachers' Beliefs: What Are They? Which Have Been Examined? what Can They Tell Us?," in APA Educational Psychology Handbook: Individual Differences and Cultural and Contextual Factor. Editors K. R. Harris, S. Graham, and T. Urdan (Washington: American Psychological Association), 471-499. doi:10.1037/13274-019

Fives, H., Lacatena, N., and Gerard, L. (2015). "Teachers' Beliefs about Teaching (And Learning)," in International Handbook of Research on Teachers' Beliefs. Editors H. Fives and M. G. Gill (New York: Routledge), 249-265.

Glasersfeld, E. v. (2001). "Einführung in Den Radikalen Konstruktivismus [Introduction to Radical Constructivism]," in Die erfundene Wirklichkeit. Wie wissen wir, was wir zu wissen glauben? Beiträge zum Konstruktivismus [The invented reality. How do we know what we think we know? Contributions to constructivism. Editor P. Watzlawick (München, 16-38.

Gregoire, M. (2003). Is it a challenge or a Threat? A Dual-Process Model of Teachers' Cognition and Appraisal Processes during Conceptual Change. Educ. Psychol. Rev. 15 (2), 147-179. doi:10.1023/a:1023477131081

Gröschner, A., Schmitt, C., and Seidel, T. (2013). Veränderung subjektiver Kompetenzeinschätzungen von Lehramtsstudierenden im Praxissemester. Z. für Pädagogische Psychol. 27 (1-2), 77-86. doi:10.1024/1010-0652/a000090

Großschedl, J., Welter, V., and Harms, U. (2019). A New Instrument for Measuring Pre-Service Biology Teachers' Pedagogical Content Knowledge: The PCK-IBI. J. Res. Sci. Teach. 56 (4), 402-439.

Handal, B. (2003). Teachers' Mathematical Beliefs A Review. The Math. Educator 13 (2), 47-57.

Hartinger, A., Kleickmann, T., and Hawelka, B. (2006). Der Einfluss von Lehrervorstellungen zum Lernen und Lehren auf die Gestaltung des Unterrichts und auf motivationale Schülervariablen. ZfE 9, 110-126. doi:10.1007/s11618-006-0008-1

Hatton, N., and Smith, D. (1995). Reflection in Teacher Education: Towards Definition and Implementation. Teach. Teach. Edu. 11 (1), 33-49. doi:10.1016/ 0742-051x(94)00012-u

Hayes, A. F. (2018). Introduction to Mediation, Moderation, and Conditional Process Analysis. 2nd Ed. New York: The Guilford Press.

Hellmann, K. (2019). "Kohärenz in der Lehrerbildung - Theoretische Konzeptionalisierung," in Kohärenz in der Lehrerbildung. Theorien, Modelle und empirische Befunde [Coherence in teacher education. Theories, models and empirical findings]. Editors K. Hellmann, J. Kreutz, M. Schwichow, and K. Zaki (Wiesbaden: Springer Fachmedien), 9-30. doi:10.1007/978-3-658-23940-4_2

Huber, L. (2009). "Warum Forschendes Lernen nötig und möglich ist [Why research-based learning is necessary and possible]," in Forschendes Lernen im Studium [Research-based learning during academic studies]. Editors L. Huber, J. Hellmer, and F. Schneider (Bielefeld: Universitätsverlag Webler), 9-35.

Huibregtse, I., Korthagen, F., and Wubbels, T. (1994). Physics Teachers' Conceptions of Learning, Teaching and Professional Development. Int. J. Sci. Edu. 16 (5), 539-561. doi:10.1080/0950069940160505

Kagan, D. M. (1992b). Implication of Research on Teacher Belief. Educ. Psychol. 27 (1), 65-90. doi:10.1207/s15326985ep2701_6

Kagan, D. M. (1992a). Professional Growth Among Preservice and Beginning Teachers. Rev. Educ. Res. 62, 129-169. doi:10.3102/00346543062002129

Kellner, E., Gullberg, A., Attorps, I., Thorén, I., and Tärneberg, R. (2011). Prospective Teachers' Initial Conceptions about Pupils' Difficulties in Science and Mathematics: a Potential Resource in Teacher Education. Int. J. Sci. Math. Educ. 9, 843-866. doi:10.1007/s10763-010-9232-5

Kleickmann, T., Richter, D., Kunter, M., Eisner, J., Besser, M., Krauss, S., et al. (2012). Teachers' Content Knowledge and Pedagogical Content Knowledge: The Role of Structural Differences in Teacher Education. J. Teach. Edu. 64 (90), 90-106. doi:10.1177/0022487112460398

Kleickmann, T., Vehmeyer, J., and Möller, K. (2010). Zusammenhänge zwischen Lehrervorstellungen und kognitivem Strukturieren im Unterricht am Beispiel von Scaffolding-Maßnahmen [Connections between teacher conceptions and cognitive structuring in the classroom using scaffolding as examples]. Unterrichtswissenschaft 38 (3), 210-228.

Kleickmann, T. (2008). Zusammenhänge fachspezifischer Vorstellungen von Grundschullehrkräften zum Lehren und Lernen mit Fortschritten von Schülerinnen und Schülern im konzeptuellen naturwissenschaftlichen Verständnis [Connections between primary school teachers' subject-related 
conceptions regarding teaching and learning with the progress students make concerning their conceptual understanding in the sciences] (Doctoral dissertation). Münster: Westfälische-Wilhelms-Universität.

Klinghammer, J., Rabe, T., and Krey, O. (2016). Unterrichtsbezogene Vorstellungen von Lehramtsstudierenden der Physik. ZfDN 22 (1), 181-195. doi:10.1007/s40573-016-0049-9

Koballa, T., Graber, W., Coleman, D. C., and Kemp, A. C. (2000). Prospective Gymnasium Teachers' Conceptions of Chemistry Learning and Teaching. Int. J. Sci. Edu. 22 (2), 209-224. doi:10.1080/095006900289967

Kohli, M. (1986). “Antizipation, Bilanzierung, Irreversibilität. Dimensionen der Auseinandersetzung mit beruflichen Problemen im mittleren Erwachsenenalter [Anticipation, balancing, irreversibility. Dimensions of dealing with professional problems in the middle-age stage of life]," in Lebenslage, Lebensalter, Lebenszeit. Editor K. Hurrelmann (Weinheim: Beltz), 123-136.

Krauss, S., Neubrand, M., Blum, W., Baumert, J., Brunner, M., Kunter, M., et al. (2008). Die Untersuchung des professionellen Wissens deutscher MathematikLehrerinnen und -Lehrer im Rahmen der COACTIV-Studie [Researching professional knowledge of German maths teachers within the framework of the COACTIV Study]. J. für Mathematikdidaktik 29 (3/4), 223-258. doi:10.1007/bf03339063

Lienert, G. A., and Raatz, U. (1998). Testaufbau und Testanalyse [Test setup and analysis]. Weinheim: Beltz.

Lloyd, G. M., and Wilson, M. (1998). Supporting Innovation: The Impact of a Teacher's Conceptions of Functions on His Implementation of a Reform Curriculum. Jrme 29 (3), 248-274. doi:10.5951/jresematheduc.29.3.0248

Lortie, D. C. (1975). Schoolteacher: A Sociological Study. Chicago, IL: University of Chicago Press.

Magnusson, S., Krajcik, J., and Borko, H. (1999). "Nature, Sources and Development of Pedagogical Content Knowledge for Science Teaching," in Examining Pedagogical Content Knowledge. Editors J. Gess-Newsome and N. G. Lederman (Dordrecht: Kluwer), 95-132.

Markic, S., and Eilks, I. (2013). Potential Changes in Prospective Chemistry Teachers' Beliefs about Teaching and Learning-A Cross-Level Study. Int. J. Sci. Math. Educ. 11, 979-998. doi:10.1007/s10763-013-9417-9

Markic, S., Valanides, N., and Eilks, I. (2006). "Freshman Science Student Teachers' Beliefs on Science Teaching and Learning-A Mixed Methods Study," in Towards Research-Based Science Teacher Education. Editors I. Eilks and B. Ralle (Aachen: Shaker-Verlag), 29-40.

Marsch, S., Hartwig, C., and Krüger, D. (2009). Lehren und Lernen im Biologieunterricht. Ein Kategoriensystem zur Beurteilung konstruktivistisch orientierter Lernumgebungen [Teaching and learning in biology lessons. A classification system to assess constructivist-oriented learning environments]. Z. für Didaktik der Naturwissenschaften 15, 109-130.

Mellado, V., Bermejo, M. L., Blanco, L. J., and Ruiz, C. (2007). The Classroom Practice of a Prospective Secondary Biology Teacher and His Conceptions of the Nature of Science and of Teaching and Learning Science. Int. J. Sci. Math. Educ. 6, 37-62. doi:10.1007/s10763-007-9081-z

Meyer, H., Tabachnick, B. R., Hewson, P. W., Lemberger, J., and Park, H.-J. (1999). Relationships between Prospective Elementary Teachers' Classroom Practice and Their Conceptions of Biology and of Teaching Science. Sci. Ed. 83 (3), 323-346. doi:10.1002/(sici)1098-237x(199905)83:3<323::aid-sce4>3.0.co;2-e

Nespor, J. (1987). The Role of Beliefs in the Practice of Teaching. J. Curriculum Stud. 19 (4), 317-328. doi:10.1080/0022027870190403

Pajares, M. F. (1992). Teachers' Beliefs and Educational Research: Cleaning up a Messy Construct. Rev. Educ. Res. 62, 307-332. doi:10.3102/ 00346543062003307

Patrick, H., and Pintrich, P. R. (2001). "Conceptual Change in Teachers' Intuitive Conceptions of Learning, Motivation, and Instruction: The Role of Motivational and Epistemological Beliefs," in Understanding and Teaching the Intuitive Mind: Student and Teacher Learning. Editors B. Torff and R. J. Sternberg (Mahwah, NJ: Lawrence Erlbaum Associates), 117-143.

Philipp, R. A. (2007). "Mathematics Teachers' Beliefs and Affect," in Second Handbook of Research on Mathematics Teaching and Learning. Editor F. K. Lester (Charlotte: CTM/Information Ages Publishing), 257-315.

Porcaro, D. (2011). Applying Constructivism in Instructivist Learning Cultures. Multicultural Ed. Tech. Jnl 5 (1), 39-54. doi:10.1108/17504971111121919
Prawat, R. S. (1992). Teachers' Beliefs about Teaching and Learning: A Constructivist Perspective. Am. J. Edu. 100 (3), 354-395. doi:10.1086/ 444021

Reinmann, G., and Mandl, H. (2006). "Unterrichten und Lernumgebungen gestalten [Teaching and setting up learning environments]," in Pädagogische Psychologie. Editors A. Krapp and B. Weidenmann (Weinheim: Beltz), 615-658.

Richardson, V. (2003). "Preservice Teachers' Beliefs," in Teacher Beliefs and Classroom Performance: The Impact of Teacher Education. Editors J. Raths and A. C. McAninch (Greenwich, Connecticut: Information Age Publishing), 1-22.

Richardson, V. (1996). "The Role of Attitudes and Beliefs in Learning to Teach," in Handbook of Research on Teacher Education. Editor J. Sikula. 2nd ed. (New York: Macmillan), 102-119.

Schön, D. A. (1987). Educating the Reflective Practitioner. San Francisco: JosseyBass.

Simmons, P. E., Emory, A., Carter, T., Coker, T., Finnegan, B., Crockett, D., et al. (1999). Beginning Teachers: Beliefs and Classroom Actions. J. Res. Sci. Teach. 36 (8), 930-954. doi:10.1002/(sici)1098-2736(199910)36:8<930:aid-tea3>3.0.co;2-n

Skamp, K., and Mueller, A. (2001). Student Teachers' Conceptions about Effective Primary Science Teaching: A Longitudinal Study. Int. J. Sci. Edu. 23 (4), 331-351. doi:10.1080/09500690119248

Schumacher, F., Großmann, N., Eckes, A., Hüfner, C., and Wilde, M. (2018). Lehrund Lernvorstellungen angehender Biologielehrender im Kontext des Praxissemesters [The Conceptions of Preservice Biology Teachers Concerning Teaching and Learning in the Context of a Practice-Based Preservice Teaching Semester]. Zeitschrift für Didaktik der Biologie (ZDB) Biologie Lehren Lernen 22 (1), 31-48.

Schumacher, F., and Wilde, M. (2021). When Prospective Biology Teachers Visualize Their Beliefs about Teaching and Learning by Drawing it, is it More than a Reproduction of Their Experienced School Lessons? Eur. J. Educ. Res. 10 (2), 799-811. doi:10.12973/eu-jer.10.2.799

Southerland, S. A., and Gess-Newsome, J. (1999). Preservice Teachers' Views of Inclusive Science Teaching as Shaped by Images of Teaching, Learning, and Knowledge. Sci. Ed. 83 (2), 131-150. doi:10.1002/(sici)1098-237x(199903)83: $2<131$ ::aid-sce3 $>3.0$. co; $2-\mathrm{x}$

Staub, F. C., and Stern, E. (2002). The Nature of Teachers' Pedagogical Content Beliefs Matters for Students' Achievement Gains: Quasi-Experimental Evidence from Elementary Mathematics. J. Educ. Psychol. 94, 344-355. doi:10.1037/00220663.94.2.344

Stipek, D. J., Givvin, K. B., Salmon, J. M., and MacGyvers, V. L. (2001). Teachers' Beliefs and Practices Related to Mathematics Instruction. Teach. Teach. Edu. 17, 213-226. doi:10.1016/s0742-051x(00)00052-4

Stofflett, R. T., and Stoddart, T. (1994). The Ability to Understand and Use Conceptual Change Pedagogy as a Function of Prior Content Learning Experience. J. Res. Sci. Teach. 31, 31-51. doi:10.1002/tea.3660310105

Stofflett, R. T. (1994). The Accommodation of Science Pedagogical Knowledge: The Application of Conceptual Change Constructs to Teacher Education. J. Res. Sci. Teach. 31, 787-810. doi:10.1002/tea.3660310804

Terhart, E. (2003). Constructivism and Teaching: a New Paradigm in General Didactics?. J. Curriculum Stud. 35 (1), 25-44. doi:10.1080/ 00220270210163653

Treagust, D. F., Duit, R., and Fraser, B. J. (1996). Improving Teaching and Learning in Science and Mathematics. New York: Teachers College Press.

Voss, T., Kleickmann, T., Kunter, M., and Hachfeld, A. (2013). "Mathematics Teachers' Beliefs," in Cognitive Activation in the Mathematics Classroom and Professional Competence of Teachers-Results from the COACTIV Project. Editors M. Kunter, J. Baumert, W. Blum, U. Klusmann, S. Krauss, and M. Neubrand (New York, NY: Springer), 249-271. doi:10.1007/978-1-46145149-5_12

Weißeno, G., Weschenfelder, E., and Oberle, M. (2013). "Konstruktivistische und transmissive Überzeugungen von Referendar/-innen [Constructivist and transmissive beliefs of teacher trainees]," in Lehrer- und Schülerforschung in der politischen Bildung [Teacher and student research in political education]. Editor A. Besand (Schwalbach am Taunus: Wochenschau Verlag), 68-77.

Widodo, A., and Duit, R. (2005). Konstruktivistische Lehr-Lern-Sequenzen und die Praxis des Physikunterrichts [Constructivist teaching-learning sequences and the practice of teaching physics]. Z. für Didaktik der Naturwissenschaften 11, $131-146$. 
Widodo, A., and Duit, R. (2004). Konstruktivistische Sichtweisen vom Lehren und Lernen und die Praxis des Physikunterrichts [Constructivist views of teaching and learning and the practice of teaching physics]. Z. für Didaktik der Naturwissenschaften 10, 233-255.

Windschitl, M. (2003). Inquiry Projects in Science Teacher Education: What Can Investigative Experiences Reveal about Teacher Thinking and Eventual Classroom Practice?. Sci. Ed. 87, 112-143. doi:10.1002/sce.10044

Woolfolk Hoy, A., Davis, H., and Pape, S. J. (2006). "Teacher Knowledge and Beliefs," in Handbook of Educational Psychology. Editors P. A. Alexander and P. H. Winne (Mahwah, NJ: Lawrence Erlbaum), 715-737.

Yilmaz, K. (2011). The Cognitive Perspective on Learning: Its Theoretical Underpinnings and Implications for Classroom Practices. The Clearing House: A J. Educ. Strateg. Issues Ideas 84 (5), 204-212. doi:10.1080/00098655.2011.568989

Zaruba, N., Westphal, A., Gutmann, F., and Vock, M. (2021). Preservice Teachers' Implicit and Explicit Attitudes towards Teaching and Learning. Front. Educ. 6, 619098. doi:10.3389/feduc.2021.619098
Conflict of Interest: The authors declare that the research was conducted in the absence of any commercial or financial relationships that could be construed as a potential conflict of interest.

Publisher's Note: All claims expressed in this article are solely those of the authors and do not necessarily represent those of their affiliated organizations, or those of the publisher, the editors and the reviewers. Any product that may be evaluated in this article, or claim that may be made by its manufacturer, is not guaranteed or endorsed by the publisher.

Copyright (c) 2021 Schumacher, Basten, Großschedl, Klatthaar and Wilde. This is an open-access article distributed under the terms of the Creative Commons Attribution License (CC BY). The use, distribution or reproduction in other forums is permitted, provided the original author(s) and the copyright owner(s) are credited and that the original publication in this journal is cited, in accordance with accepted academic practice. No use, distribution or reproduction is permitted which does not comply with these terms. 